\section{Bad manners, USA}

SIR - I recently had the pleasure of participating at the XVth International Congress of Genetics in New Delhi. I would like to congratulate my Indian colleagues for their successful effort. The congress was well organized, the atmosphere was friendly and congenial and the subjects covered were interesting and diverse. It was one of the best international congresses in the past few years.

However, I feel bound to apologize to the Indian organizers for the rude, inexcusable and unacceptable behaviour of a number of my American colleagues who never appeared at plenary sessions or symposia (as chairmen or as speakers). Their names were called without answer. Obviously their commitment to a "developing" country's meeting was not binding. Furthermore, quite a few failed to send a summary of the paper they were presenting at a symposium. Maybe they do not know that Indian students and young scientists are more eager to read than their counterparts in the United States.

ANNAMARIA TORRIANI-GORINI Department of Biology,

Massachusetts Institute of Technology, Cambridge, Massachusetts 02139, USA

\section{Israel squeezed out}

SIR - Israeli scientists will not be able to participate in the 7 th International Biotechnology Symposium to be held in New Delhi, India, 19-24 February 1984.

According to the organizers, scientists from countries without an Indian Mission will obtain entry permits/visas if the organizers are contacted at least six months before the symposium. Since July 1983, I have been trying to obtain information on how to apply for a visa, but to no avail. This symposium is sponsored by international organizations such as the International Committee on Economic and Applied Microbiology and the International Union of Pure and Applied Chemistry and should therefore be open to scientists from all countries of the world.

I call upon fellow scientists to boycott this meeting to show their solidarity and to protest to the organizers and the Indian Government that scientists from all countries cannot participate in the New Delhi meeting. The Indian Government's attitude should also be kept in mind when selecting sites for future international meetings.

J. STEFAN RoKem

Department of Applied Microbiology, Hebrew University of Jerusalem, Israel

\section{Creationist view}

SIR - Professor Marsden overlooks some important points and makes some logical errors in his recent commentary on the history and sociology of the creation/evolution debate ${ }^{\prime}$. In his search for a hidden agenda in creationism, he overlooks the legitimate scientific case for creation, and he does not deal with possible philosophical, political, and economic motivations of the other group which seeks to polarize the debate - the evolutionary humanists ${ }^{2}$

He complains about the polarization of the issue as if a middle ground of progressive creationism, based on directed macro-evolution and an old Earth, is supported by scientific data. Professor Marsden has misunderstood radiometric dating and the geological time scale as simple scientific facts (SSFs), just like Newton's third law or the fact that a granite contains potash, feldspar and quartz.

If there were SSFs which indicated that the Earth is old and precluded fiat creation, then his point would be well taken. But the methods of evolutionary/uniformitarian geochronology, historical geology and palaeoenvironmental analysis are not SSFs, but rather complex scientific models (CSMs) involving many assumptions, some of which are demonstrably wrong, such as pleochroic haloes in granitic rocks, which are held to prove the constancy of radioactive decay rates through Earth history. Some of these data which argue against the doctrine of uniformity have even been published in Nature ${ }^{3}$. The historical assertions that the Cambrian began about 600 million years ago and that the Scopes trial began in 1925 are not equivalent concepts and, as such, should not be taught in the same breath to unwitting students.

Professor Marsden is also wrong in his thesis that we creationists are only a product of some "Post-Civil War cultural crisis". Creationists are convinced by coercive scientific data ${ }^{4}$, not solely by conservative theology, demography or profession.

As a fundamentalist, southerner and geologist, I resent several accusations made by Marsden and the implication that a conservative exegesis of Genesis 9 can support slavery. and that this is part of southern creationists' motivation. I also question his assertion that many southern antievolutionists are made because of "the relatively low levels of education of many Southern Bible-believers". I am a creationist because the basic facts of geology (and the other sciences) are consistent with fiat creation and several thousand years of Earth history dominated, during brief periods, by processes of catastrophic rate, on a continental scale and of high intensity ${ }^{5}$.

Geology Section,

DAVID R. MCQUEEN

Institute for Creation Research,

El Cajon,

California 92021, USA

1. Marsden, G.M. Nature 306, 528-532 (1983)

Dunphy, J. The Humanist 43, 26 (1983)

Gentry, R.V. Nature 244, 282 (1973).

Morris, H.M. \& Parker, G.E. What is Creation Science? (San Diego, CLP, 1982).

5. Ager, D.V. The Nature of the Stratigraphical Record (Wiley, New York, 1981)

\section{Page charge problem}

SIR - In scientific publishing a symbiotic equilibrium had been established in which referees evaluate, without payment, papers submitted for publication, in the knowledge that refereeing and publication of papers they themselves submit will be carried out without cost to them. Unfortunately, this equilibrium has been disturbed by a considerable number of (I think exclusively) US journals which now require the prospective author to pay for publication. Many people are therefore being asked to contribute to the publication of journals both by giving free service as referees and also by paying "page charges".

I understand that provision is made on many US research grants for the cost of publication. This is not so in Europe, and it is a practice which, in effect, discriminates against non-US scientists wishing to publish in US journals. Whilst the practice eases the problem for US scientists, the principle of working for, and paying to publish in, the journal seems wrong.

None of us expects or wants payment for refereeing manuscripts. The situation as it existed for many years (and still exists in Europe) was a mutual-help system to which we contributed and from which we benefited. But many scientists and their financiers are unhappy at the extra financial load imposed by some journals.

As a partial solution I propose that referees should ask for page-charge credits which could, wholly or in part, be used to offset the cost of their next publication. In this way no money would change hands and work done by the reviewer would simply result in the amelioration of an added financial burden upon research institutions. The best arrangement, of course, would be to return to the original equilibrium where we paid, and were paid, nothing.

Paterson Laboratories,

R. SCHOFIELD

Christie Hospital \&

Holt Radium Institute,

Manchester M20 9BX, UK

\section{Sea cow born again?}

SIR - If Steller's sea cow was first discovered in 1759 (as Vera Rich claims in Nature 306, 415; 1983) how did the mining engineer, Retr Yakovlev know it was the "Kapustnik" and fear its extinction in 1755 ?

R. PARR

Miterdale Farm, Arrington, Royston, Herts. SG8 OAE, UK

Vera Rich responds: Rhytina stelleri

Became extinct early,

After brief fame begun

In 1741 .

(1759 was a printer's error). 